\title{
Effects of comparative advantage on exports: A case study of Iranian industrial subsectors
}

\author{
Masoud Nonejad*, Samira Zamani \\ Islamic Azad University of Shiraz, Iran \\ *mnonejad.iaushiraz@yahoo.com
}

\begin{abstract}
One of the informational requirements in planning import and export activities is to an awareness of a country's comparative advantage in the production of goods and services. The present paper attempts to assess Iran's Revealed Comparative Advantage (RCA) in industrial subsectors based on two-digit code of the International Standard Industrial Classification (ISIC) and effects of five top subsectors with the highest average of RCA on the total Iranian real industrial exports. RCAs for Iranian industrial subsectors (during 2001-2010) were calculated for 2001-2010 time period and seasonal data (2001-2010) were collected to estimate the RCA Model. Auto Regressive Distributed Lags (ARDL) Method was employed to investigate the effects of these subsectors on the total Iranian real industrial exports. The econometric results show that the subsectors with highest RCA average have a positive and significant effect on the total Iranian real industrial exports.
\end{abstract}

Key words: Revealed Comparative Advantage, Iranian industrial subsectors, Auto Regressive Distributed Lags (ARDL), Error Correction Model (ECM)

\section{Introduction}

Today, foreign trade comprises a significant part of economic activities in many countries throughout the world. Besides, the significance and the role of foreign trade in the countries' economic development have been rising since the early $19^{\text {th }}$ century due to an unprecedented growth in the global economy. As a result, only those countries can take the initiative in solving import and export related problems that have made specific plans concerning their long-term socioeconomic objectives. One of the informational requirements in planning import and export activities is to have an awareness of a country's comparative advantage for the production of goods and services. In order to study export comparative advantage, Balassa (1965) derived an index that measured a country's comparative advantage. The Balassa Index tries to show whether a given country has a "revealed" comparative advantage rather than to determine the underlying sources of comparative advantage (Utkulu and Seymen, 2004). The comparative advantage, in general, reveals a nation's capabilities in manufacturing and exporting a commodity in cooperation with other countries. The increasing importance of gaining independence from oil revenues, due to the fluctuations and volatility of oil prices and the severe effects of oil global markets on the revenues of oil-exporting countries, has made non-oil exports as a means to obtain foreign currency income. Industrial exports are always considered as one of the major issues in the field of "non-oil exports". Today, the development of exportation of industrial goods is regarded as an inevitable requirement because it can increase foreign currency income and, thus, make it possible to implement economic development programs which involve considerable foreign currency costs. Fluctuations in foreign currency income require formulation of some policies in order to increase the exports of industrial products. As a result, the identification of those Iranian industrial subsectors with a comparative advantage seems of high significance. This paper attempts to assess Iran's Revealed Comparative Advantage (RCA) in industrial subsectors based on two-digit code of the International Standard Industrial Classification (ISIC) for (2001-2010) and effects of five top subsector with the highest average of RCA on the total Iranian real industrial exports.

\section{Literature Review}

Theory of Absolute Advantage by Smith (1776) was based on the idea that each country produces and exports only the goods that country is more efficient in their production than other countries. The Comparative Advantage Theory assumes that a country with the greatest absolute advantage and the lowest 
opportunity cost than another country attempts to produce a product. However, due the basic assumptions of this theory, it was faced with a number of criticisms. The neo-classical trade theory was composed by the factor endowment theory (Ohlin, 1933) and the resource endowment theory by Samuelson, 1941. Different theories were proposed by economists after these theories, suggesting that besides labor, abundance of natural resources, and raw materials factors, some other factors such as research and development, technology, human resources skills, consumers' preferences, and market conditions are effective in the creation of comparative advantage for different countries. Lin et al. (1996) argued that a comparative advantage strategy is the best option for the economic growth. Because different goods require different combinations of factor inputs, each economy should choose the most advantageous industrial structure based on its resource endowments. The structure of factor endowments and the relative abundance of factors of production within a given economy depend both on the natural endowments of that economy and on its economic development level. Changjun and Ping (2002) used Revealed Comparative Advantage (RCA) Index for China and Chinese provinces at one digit level of Standard International Trade Classification (SITC). They used the RCA index to demonstrate the fact that China has changed its export patterns in such a way to coincide with its comparative advantage and that there are distinct differences in export patterns between the coastal regions and the interiors in China. Utkulu and Seymen (2004) used Revealed Comparative Advantage (RCA) index to study Turkey's comparative advantage. The result of RCAs obtained for the various commodity groups show that clothing, fruits and vegetables, sugar, honey, tobacco, vegetable oils, rubber industries, textiles, fabrics, and related products of these three commodity groups enjoy comparative advantage among EU Member States and this is a strategy used by Turkey to join the EU. Smyth (2005) used Revealed Comparative Advantage (RCA) index at one digit level of Standard International Trade Classification (SITC) to measure comparative advantage in Ireland. The results of RCA measurement indicate that Ireland has comparative advantage in chemical, pharmaceutical, food, live animals markets.

Serin and Civan (2008) examined Turkey's revealed comparative advantage and competition in Europe Union during the time period of 1995-2005. They employed revealed comparative advantage index and comparative performance in tomato, olive oil and juice industries. The results show that Turkey have comparative advantage in olive oil and juice industries in EU market, but tomato industry has no comparative advantage in the EU market. Ghazijahani (2000) investigated the comparative advantage in Iran's industries. The results of the study indicate that Iran has comparative advantage in textiles, clothing, leather, paper, and publishing industrial subsectors. Jahangiri et al., (2001) examined the comparative advantage and the priority of export markets for Iranian fur and leather industries by employing Revealed Symmetric Comparative Advantage (RCSA). They found that Iran enjoys a comparative advantage in the export of fur and leather. Monjazeb (2002) used Revealed Comparative Advantage (RCA) index for Iran's food and cloth industries during 1993 1997. The results of his study suggest that Iran has lost its share in global markets and that the Iran's comparative advantage for food and clothing industries has experienced a relative decline. Dashti et al., (2010) used Revealed Comparative Advantage (RCA) and Revealed Symmetric Comparative Advantage (RCSA) indexes to investigate the comparative advantage of Iran's pistachio. The results were indicative of a considerable difference in the comparative advantage of Iran's comparative advantage over the other pistachio exporting countries. However, this comparative advantage has been declining over the period under study. According to the results of the previous studies, it was noted that Iran has comparative advantage in different subsectors and since industrial subsectors are of vital importance in the country's economic development, the present study tries investigating the RCA index for Iranian industrial subsectors and uses this index as a regressor in export equations.

\section{Methodology}

The classic international trade theory based on differences in factors of proportion was developed in its neoclassical form by Heckscher and Ohlin (HO) to explain the underlying reasons for trade and to predict the trade patterns used by different countries. Countries with large amounts of land and minerals are expected to export more goods and commodities. Comparative advantage in association with international trade indicates that if a country can produce a given good at a lower cost than other goods, the country has a comparative advantage in the production of such a good and it can take advantage by entering the international trade 
market by exporting those goods that enjoy a comparative advantage ${ }^{1}$. RCA is one of the export comparative advantage indices, used for the first time by Balassa (1965) to evaluate the export yields and different goods. Balassa (1965) suggests that perhaps it is not necessary to include all constituents affecting a country's comparative advantage. Instead, he believes that comparative advantage should be "revealed" by observed trade patterns, and in line with the theory, one needs to assess pre-trade relative prices which are not observable. Thus, inferring comparative advantage from observed data is called "revealed" comparative advantage (RCA). In practice, this is a commonly accepted practice to analyze trade data (Utkulu and Seymen, 2004). In this paper, we use Balassa's (1965) measure of relative export performance, defined as a country's share of world exports of a commodity divided by its share of total world exports. The Index is measured as follows (Equation 1):

$$
R C A_{i j}=\left(x_{i j} / x_{j}\right) /\left(x_{i w} / x_{w}\right)
$$

Where $\mathrm{X}$ is exports, $i$ sector, $j$ the country, and $w$ represents the world.

If the value of this index is located at the distance $(0,1)$ it means that a given country has no comparative advantage in that sector. On the other hand, if the distance varies from 1 to infinite values, the country in question enjoys comparative advantage in the given sector and it moves towards specialization in production and exportation. This method encompasses all the factors affecting comparative advantage such as factors of production, supply and demand, and exports. Besides, the method represents the true comparative advantage of a given country. According to the Balassa, the above index, relying on the existing structure of exports, is an appropriate tool to investigate whether a given country is able to join the WTO or not and also to assess possible long-term effects of commercial liberalization ${ }^{2}$. In the present study, RCA index has been calculated for all industrial subsectors based on the ISIC two-digit code (See Table 1). In addition, using an average RCA index, the five top subsectors with the highest average of RCA were determined and effects of each subsector on the total real industrial exports were measured through Real Exports Function (Cerra \& Dayal-Gulati, 1999; Goldstein \& Khan, 1985) derived from export supply and demand function (Equation 2):

$$
\text { Lnx }=c_{0}+c_{1} \text { Lner }_{t}+c_{2} \text { Lngdp } p_{t}^{w}+c_{3} \text { Lngd }_{t}^{i}+c_{j} R C A_{j}
$$

Where $\ln x$ is the logarithm of real industrial exports, lner is the logarithm of the real effective currency rate, $\operatorname{lngdp}_{t}$ the world's GDP, lngdp ${ }_{t}{ }_{t}$ shows Iran's GDP, and $\mathrm{RCA}_{1}$ is revealed comparative advantage in Iran's industrial subsectors.

\section{Results and Discussion}

Revealed comparative advantage in Iran's industrial subsectors: The values of all variables under study in the time period of 2001 to 2009 were collected from the data available at the Trade Statistics Yearbook of Customs of Islamic Republic of Iran and the International Trade Center (ITC) and the values of RCA index have been given in (Table 1), upon which the following results were obtained:

- Chemical products and other non-metallic production industries have benefited from comparative advantage in the whole period under study.

- Production of tobacco, wood, cork for consumption other than furniture, products made from bamboo and straw materials, production of paper and paper products, publishing, printing and reproduction of the press, machinery and equipment not classified elsewhere, administrative, calculating, and computing machines, motor vehicles, trailers and semi-trailers, and other transport equipment, furniture products not classified elsewhere were all without comparative advantage during the period under study.

- Food and beverage industry, textile and leather production, processing and manufacturing leather bags, suitcase and saddle, harness, and footwear enjoyed comparative advantage during the period under study, except in 2009.

- Production of coke, oil refineries, and nuclear fuels benefitted comparative advantage during the period under study except for 2002 .

\footnotetext{
${ }^{1}$ Naderi, A. (2006). Comparative advantage and development of Iran's exports. Institution of Business Research and Studies Center, p38.

${ }^{2}$ Valibeigi, H., \& Rahimialmasi, F. (2004). An analysis of comparative advantage in Iran's tweedy-weaving industry. Journal of Business, 30, 188-189.
} 
- Production of basic metals enjoyed comparative advantage during the period under study except for 2001 and 2008.

- Production of fabricated metal products except for machinery and equipment has enjoyed comparative advantage only in 2001, 2002, and 2003.

- Production of rubber and plastic products benefitted from comparative advantage during the period under study, except for 2004 and 2007.

- Production of clothing, processing, and dying furs has benefitted from comparative advantage from 2001 to 2009 but it did not possess comparative advantage in the remaining years of the period under study.

- Based on the calculated average of the comparative advantage, production of textile, coke, oil refineries, nuclear fuels, chemical products, other non-metallic mineral products, and basic metals has had the highest rate of comparative advantage.

Table 1: RCA and its average in Iranian industrial subsectors

\begin{tabular}{|c|c|c|c|c|c|c|c|c|c|c|c|}
\hline \multirow{2}{*}{$\begin{array}{l}\text { Two } \\
\text { digit } \\
\text { ISIC }\end{array}$} & \multirow{2}{*}{ Products } & \multicolumn{9}{|c|}{ RCA } & \multirow{2}{*}{$\begin{array}{r}\text { RCA } \\
\text { Average }\end{array}$} \\
\hline & & 2001 & 2002 & 2003 & 2004 & 2005 & 2006 & 2007 & 2008 & 2009 & \\
\hline 15 & Food and beverage & 2.89 & 3.04 & 5.10 & 1.56 & 1.61 & 3.66 & 1.64 & 1.17 & 0.31 & 2.33 \\
\hline 16 & Tobacco products & 0.44 & 0.006 & 0.72 & 0.24 & 0.10 & 0.13 & 0.01 & 0.01 & 0.01 & 0.18 \\
\hline 17 & Textiles & 10.47 & 11.00 & 15.14 & 4.68 & 3.66 & 5.61 & 2.26 & 1.90 & 0.07 & $\begin{array}{r}6.09 \\
1^{*}\end{array}$ \\
\hline 18 & $\begin{array}{l}\text { Clothing, processing } \\
\text { and dying fur } \\
\text { leather production, } \\
\text { processing and } \\
\text { manufacturing }\end{array}$ & 1.89 & 2.43 & 3.16 & 0.74 & 0.50 & 0.70 & 0.21 & 0.15 & 6.62 & 1.82 \\
\hline 19 & $\begin{array}{lr}\text { leather } & \text { bags, } \\
\text { suitcase, } & \text { saddle, } \\
\text { harness, } & \text { and } \\
\text { footwear } & \end{array}$ & 4.42 & 4.64 & 6.71 & 1.91 & 1.64 & 2.98 & 1.17 & 1.03 & 0.07 & 2.73 \\
\hline 20 & $\begin{array}{l}\text { Wood and cork for } \\
\text { consumption other } \\
\text { than furniture, } \\
\text { products made from } \\
\text { bamboo and straw } \\
\text { materials }\end{array}$ & 0.24 & 0.37 & 0.006 & 0.11 & 0.20 & 0.54 & 0.26 & 0.15 & 0.03 & 0.21 \\
\hline 21 & $\begin{array}{l}\text { Paper and paper } \\
\text { products }\end{array}$ & 0.32 & 0.44 & 0.73 & 0.21 & 0.19 & 0.56 & 0.1 & 0.10 & 0.05 & 0.30 \\
\hline 22 & $\begin{array}{l}\text { Paper used in } \\
\text { publishing and the } \\
\text { press }\end{array}$ & 0.31 & 0.46 & 0.99 & 0.00 & 0.32 & 0.66 & 0.28 & 0.23 & 0.01 & 0.37 \\
\hline 23 & $\begin{array}{l}\text { Coke, oil refineries, } \\
\text { and nuclear fuels }\end{array}$ & 7.40 & 0.26 & 10.38 & 3.82 & 2.73 & 6.73 & 2.83 & 2.71 & 3.78 & $\begin{array}{r}4.56 \\
4^{*}\end{array}$ \\
\hline 24 & Chemical products & 2.43 & 2.88 & 3.67 & 1.73 & 1.99 & 1.36 & 2.43 & 22.85 & 2.74 & $\begin{array}{r}4.67 \\
3^{*}\end{array}$ \\
\hline 25 & $\begin{array}{l}\text { Plastic and rubber } \\
\text { products }\end{array}$ & 1.44 & 1.54 & 2.70 & 0.80 & 1.12 & 2.56 & 1.04 & 0.87 & 0.15 & 1.36 \\
\hline 26 & $\begin{array}{l}\text { Other nonmetallic } \\
\text { minerals }\end{array}$ & 4.96 & 4.80 & 8.51 & 3.20 & 3.77 & 6.05 & 2.38 & 2.14 & 14.45 & $\begin{array}{r}5.59 \\
2^{*}\end{array}$ \\
\hline 27 & Basic metals & 0.23 & 4.64 & 4.73 & 3.48 & 2.79 & 3.86 & 1.63 & 0.87 & 5.72 & $\begin{array}{r}2.9 \\
5^{*}\end{array}$ \\
\hline 28 & $\begin{array}{lr}\begin{array}{l}\text { Fabricated } \\
\text { other }\end{array} & \begin{array}{r}\text { metals } \\
\text { than }\end{array} \\
\text { machinery } & \text { and } \\
\text { equipment } & \end{array}$ & 1.69 & 1.66 & 1.92 & 0.53 & 0.63 & 0.92 & 0.33 & 0.26 & 0.1 & 0.89 \\
\hline 29 & $\begin{array}{l}\text { Machineries and } \\
\text { equipment not } \\
\text { classified elsewhere }\end{array}$ & 0.24 & 0.41 & 0.94 & 0.31 & 0.30 & 0.64 & 0.22 & 0.26 & 0.02 & 0.37 \\
\hline
\end{tabular}




\begin{tabular}{|c|c|c|c|c|c|c|c|c|c|c|c|}
\hline 30 & $\begin{array}{l}\text { Office } \\
\text { calculative } \\
\text { equipment }\end{array}$ & 0.00 & 0.00 & 0.05 & 0.01 & 0.00 & 0.016 & 0.003 & 0.00 & 0.04 & 0.00 \\
\hline 31 & $\begin{array}{l}\text { Electric devices not } \\
\text { classified elsewhere }\end{array}$ & 0.35 & 0.52 & 0.81 & 0.20 & 0.25 & 0.47 & 0.33 & 0.22 & 0.01 & 0.35 \\
\hline 32 & $\begin{array}{l}\text { Radio, TV, and mass } \\
\text { media products }\end{array}$ & 0.04 & 0.06 & 0.00 & 0.01 & 0.03 & 0.05 & 0.03 & 0.05 & 0.00 & 0.03 \\
\hline 33 & $\begin{array}{l}\text { Medical and optic } \\
\text { tools, } \\
\text { instrumentation, } \\
\text { watches ... }\end{array}$ & 0.04 & 0.07 & 0.13 & 0.09 & 0.03 & 0.06 & 0.028 & 0.03 & 0.00 & 0.05 \\
\hline 34 & $\begin{array}{l}\text { Vehicles, trailers, } \\
\text { semi-trailers }\end{array}$ & 0.026 & 0.26 & 0.33 & 0.16 & 0.19 & 0.53 & 0.38 & 0.22 & 0.02 & 0.26 \\
\hline 35 & $\begin{array}{l}\text { Other } \\
\text { transportation } \\
\text { machineries }\end{array}$ & 0.23 & 0.06 & 1.19 & 0.10 & 0.14 & 0.24 & 0.15 & 0.07 & 0.00 & 0.24 \\
\hline 36 & $\begin{array}{l}\text { Furniture and } \\
\text { products not } \\
\text { classified elsewhere }\end{array}$ & 0.32 & 0.32 & 0.79 & 0.38 & 0.49 & 0.48 & 0.11 & 0.10 & 0.00 & 0.33 \\
\hline
\end{tabular}

*Source: Research findings

*Five top industrial subsectors with the highest average of RCA have been codified as $1^{*}, 2^{*}, 3^{*}, 4^{*}$, and $5^{*}$.

The value of RCA index is higher than one (RCA > 1) for nine industrial subsectors indicating these subsectors enjoy a comparative advantage in the world market. Subsectors with a high revealed comparative advantage in Iran are chemical products, other non-metallic products, textiles, basic metals and coke, oil refineries, and nuclear fuels.

\section{Model Estimation}

Model Structure: After identification of the five industrial subsectors with the highest RCA average, Equation (2) is rewritten as Equation (3):

$$
\begin{aligned}
& \operatorname{Lnx}=c_{0}+c_{1} \text { Lner }_{t}+c_{2} \text { Lngdp }_{t}^{w}+c_{3} \operatorname{Lngdp}_{t}^{i}+c_{4} R C A 17+c_{5} R C A 23+c_{6} R C A 24+ \\
& c_{7} R C A 26+c_{8} R C A 27+u_{t}
\end{aligned}
$$

Iranian industrial subsections based on the two-digit ISIC code inserted into the model include: textiles (RCA17), nonmetallic minerals (RCA26), chemical products (RCA24), coal, coke - oil refineries and nuclear fuels (RCA23), and basic metals (RCA27), (industries with code of ISIC 17, 23, 24,26, 27), and residual sentences $\mathrm{u}_{1}$.

Stationary Test: In this study, Augmented Dickey Fuller Test (ADF) was employed to investigate the stationary of all variables in Equation (3). If the absolute value of the statistics of (ADF) is larger than the absolute value of the critical values, the variables in question will be static. The results obtained through this test, shown in Table (2), suggest that Iner and Inx are static with the order one or I (1) and the rest of variables are static or of order I(0). Critical values at level of $1 \%, 5 \%$, and $10 \%$ with equivalent are -4.29 , 3.56 , and -3.21 and without equivalent $-3.67,-2.96$, and 2.62 .

\begin{tabular}{|c|c|c|c|c|c|}
\hline \multirow[b]{2}{*}{ Variablec } & \multirow[b]{2}{*}{ Without trend } & \multirow{2}{*}{$\begin{array}{r}\text { Variable level } \\
\text { With trend }\end{array}$} & \multicolumn{2}{|c|}{$\begin{array}{l}\text { Test statistics } \\
\text { First order difference }\end{array}$} & \multirow[t]{2}{*}{$\begin{array}{c}\text { Results } \\
\text { stationary test }\end{array}$} \\
\hline & & & Without trend & With trend & \\
\hline LnX & ----- & ----- & $-2 / 95$ & $-4 / 16$ & $\mathrm{I}(1)$ \\
\hline LnER & ----- & ----- & ------ & $-7 / 65$ & I(1) \\
\hline LnGDPi & $-6 / 36$ & $-4 / 05$ & ----- & ----- & $\mathrm{I}(0)$ \\
\hline LnGDPw & $-3 / 03$ & ----- & ------ & ----- & $\mathrm{I}(0)$ \\
\hline RCA17 & ----- & $-3 / 66$ & ----- & ----- & $\mathrm{I}(0)$ \\
\hline RCA23 & $-4 / 13$ & $-4 / 62$ & ----- & ----- & $\mathrm{I}(0)$ \\
\hline RCA24 & $-3 / 26$ & $-3 / 59$ & ----- & $-\cdots--$ & $\mathrm{I}(0)$ \\
\hline RCA26 & $-3 / 65$ & $-3 / 72$ & ----- & ------ & $\mathrm{I}(0)$ \\
\hline RCA27 & $-2 / 83$ & ----- & ----- & ----- & $\mathrm{I}(0)$ \\
\hline
\end{tabular}

Table 2: Augmented Dickey Fuller Test Statistics to check in the stationary of the model variables

Source: Research findings 
Model estimation was performed after investigating the stationary of the variables. As shown by the stationary test, the variables used in the study are of order zero and one. Thus, it is possible to use AutoRegressive Distributed Lags (ARDL) Method. According to the estimation procedure, ARDL form of Equation (3) will be in the form of Equation (4):

$$
\begin{aligned}
& \ln X_{t}=\sum_{j=1}^{p} \varphi_{j} \ln X_{t-j}+\sum_{j=0}^{q 1} \beta_{1 j} \ln E R_{t-j}+\sum_{j=0}^{q 2} \beta_{2 j} \ln \operatorname{GDP}(i)_{t-j}+\sum_{j=0}^{q 3} \beta_{3 j} \ln G D P(w)_{t-j}+ \\
& \sum_{j=0}^{q 4} \beta_{4 j} R C A 17_{t-j}+\sum_{j=0}^{q 5} \beta_{5 j} R C A 23_{t-j}+\sum_{j=0}^{q 6} \beta_{6 j} R C A 24_{t-j}+\sum_{j=0}^{q 7} \beta_{7 j} R C A 26_{t-j}+ \\
& \sum_{j=0}^{q 8} \beta_{8 j} R C A 27_{t-j}+\delta \text { Trend }_{t}+u_{t}
\end{aligned}
$$

The reason for not using intercept is due to appropriate fitting of the model in conditions that there is no intercept and also empirical documentation gained through prior studies in which no intercept was employed to fit the model best. The results of estimation of the self-explaining vector model with distribution intervals related to Iranian real industrial exports during 2001:1-2009:4 have been shown in Table (3) below. Due to the small sample size, Schwars Bayesian Criterion (SBC) was employed to optimally select the model so that lower degree of freedom will be lost. Schwars Bayesian Criterion has given Lag 1 to variables (RCA24), (RCA26), and lner and Lag 0 to the other variables. The estimation of the short-term model indicates that at 95\% confidence level the variable coefficient of Iran's and the world's GDP logarithm is significant and has a positive effect on total real industrial exports. The variable coefficient of real effective currency rate logarithm is insignificant, and RCA index coefficients of non-metallic mineral products, chemical products, coke, oil refineries, nuclear fuels, basic metals and textiles are significant and have a positive effect on total real industrial exports. Besides, production of chemical and non-metallic mineral products has a significant lag, negatively affecting total real industrial exports. The results of diagnostic tests indicate that the significance level of the two LM and F statistics is greater than the error level of 5\% in these tests. As a result, the null hypothesis was confirmed at $95 \%$ level of significance, indicating that there is no auto-regression between disorder terms, the proper functional terms, distribution of disorder terms, and homogeneity variance of error terms.

Table 3: Results of estimating self-regressive model with ARDL distribution lags $(1,1,0,0,0,0,1,1,0,0)$

\begin{tabular}{lrrr}
\hline $\begin{array}{l}\text { Predicting } \\
\text { variable }\end{array}$ & Coefficient & $\begin{array}{r}\text { Standard } \\
\text { deviation }\end{array}$ & $\begin{array}{r}\text { Lnx dependant variable } \\
\text { t-statistics (level of sig) }\end{array}$ \\
\hline Lnx(-1) & $0 / 59$ & $0 / 071$ & $8 / 35[0 / 000]$ \\
Ln ER & $-4 / 84$ & $2 / 01$ & $-2 / 95[0 / 227]$ \\
Ln ER(-1) & $3 / 90$ & $2 / 72$ & $2 / 43[0 / 220]$ \\
Ln GDP i & $0 / 55$ & $0 / 38$ & $1 / 08[0 / 02]$ \\
Ln GDP w & $0 / 15$ & $0 / 08$ & $2 / 95[0 / 000]$ \\
RCA17 & $0 / 08$ & $0 / 02$ & $2 / 71[0 / 001]$ \\
RCA23 & $0 / 20$ & $0 / 04$ & $4 / 23[0 / 001]$ \\
RCA24 & $0 / 19$ & $0 / 02$ & $7 / 55[0 / 000]$ \\
RCA24(-1) & $-0 / 30$ & $0 / 03$ & $-9 / 34[0 / 000]$ \\
RCA26 & $0 / 25$ & $0 / 04$ & $6 / 32[0 / 000]$ \\
RCA26(-1) & $-0 / 09$ & $0 / 01$ & $-5 / 21[0 / 000]$ \\
RCA27 & $0 / 02$ & $0 / 02$ & $0 / 99[0 / 047]$ \\
TREND & $0 / 20$ & $0 / 04$ & $4 / 44[0 / 000]$ \\
Diagnostic Test & $\mathrm{R}^{2}=0 / 98$ & $\mathrm{DW}=2 / 1$ & $\mathrm{~F}=456 / 59[0 / 000]$ \\
\hline Sourc: Resea
\end{tabular}

Source: Research findings

Estimation of long term model: Boundary Test (Pesaran et al., 2001) was employed to ensure long-run equilibrium relationship between the model variables. F statistics obtained through the test is greater than the upper limit of critical statistics of Pesaran et al. at $10 \%$ of error level. As a result, the null hypothesis indicating that there is no long-run equilibrium relationship between the variables in the model was rejected 
and the opposite hypothesis (the existence of a long-run equilibrium relationship) was accepted. Based on long-run equilibrium relationship, the coefficients of long term model has been estimated as shown Table (4), indicating that a 95\% confidence level, the variable coefficient of Iran's and the world's GDP logarithm is significant and has a positive effect on total real industrial exports, the variable coefficient of real effective currency rate logarithm is insignificant, and, finally, RCA index coefficients for non-metallic mineral products, chemical products, coke, oil refineries, nuclear fuels, basic metals and textiles are significant and have a positive effect on total real industrial exports.

Table 4: Results of estimation of long term coefficient

\begin{tabular}{|c|c|c|c|}
\hline $\begin{array}{l}\text { Predicting } \\
\text { variable }\end{array}$ & Coefficient & $\begin{array}{c}\text { Standard } \\
\text { deviation }\end{array}$ & $\begin{array}{l}\text { Lnx dependant variable } \\
\text { t-statistics (level of sig) }\end{array}$ \\
\hline Ln ER & $-3 / 43$ & $2 / 63$ & $-0 / 88[0 / 38]$ \\
\hline Ln GDP i & $0 / 55$ & $0 / 38$ & $1 / 08[0 / 035]$ \\
\hline Ln GDP w & $0 / 15$ & $0 / 08$ & $2 / 95[0 / 001]$ \\
\hline RCA17 & $0 / 2$ & $0 / 05$ & $3 / 84[0 / 001]$ \\
\hline RCA23 & $0 / 05$ & $0 / 03$ & $1 / 48[0 / 035]$ \\
\hline RCA24 & $0 / 2$ & $0 / 04$ & $0 / 83[0 / 000]$ \\
\hline RCA26 & $0 / 41$ & $0 / 09$ & $4 / 21[0 / 001]$ \\
\hline RCA27 & $0 / 062$ & $0 / 066$ & $1 / 35[0 / 057]$ \\
\hline Trend & $0 / 51$ & $0 / 11$ & $4 / 60[0 / 047]$ \\
\hline
\end{tabular}

Source: Research findings

All coefficients of RCA17, RCA23, RCA24, RCA26 and RCA27 were positive and Iran had a comparative advantage in textile products, coke, oil refineries, nuclear fuels, chemical products, nonmetallic minerals, and basic metals as Iran has abundant resources and mines such as decorative stones, clay, salt, oil, and gas resources.

Error Correction Model: The results of error correction model for the function of total real industrial exports presented by Microfit are shown in Table 5. The value of error correction is indicative of $40 \%$ of short term disequilibrium in each period.

Table 5: error correction model for ARDL

\begin{tabular}{llll}
\hline $\begin{array}{l}\text { Predicting } \\
\text { variable }\end{array}$ & Coefficient & $\begin{array}{l}\text { Standard } \\
\text { deviation }\end{array}$ & $\begin{array}{c}\text { t-statistics (level of } \\
\text { sig) }\end{array}$ \\
\hline dLn ER & $-2 / 43$ & $3 / 01$ & $-2 / 95[0 / 007]$ \\
dLn GDP i & $0 / 32$ & $0 / 18$ & $1 / 08[0 / 025]$ \\
dLn GDP w & $0 / 09$ & $0 / 06$ & $1 / 36[0 / 000]$ \\
dRCA17 & $0 / 08$ & $0 / 02$ & $2 / 71[0 / 01]$ \\
dRCA23 & $0 / 05$ & $0 / 03$ & $1 / 48[0 / 03]$ \\
dRCA24 & $0 / 19$ & $0 / 02$ & $7 / 55[0 / 000]$ \\
dRCA26 & $0 / 25$ & $0 / 04$ & $6 / 32[0 / 000]$ \\
dRCA27 & $0 / 02$ & $0 / 02$ & $0 / 99[0 / 031]$ \\
dTrend & $0 / 20$ & $0 / 04$ & $4 / 44[0 / 000]$ \\
ECM(-1) & $-0 / 40$ & $0 / 07$ & $-5 / 61[0 / 00]$ \\
\hline
\end{tabular}

\section{Conclusion and Recommendations}

The results of the model estimation indicate that during the period under study, Iran's GDP (with the coefficient of 0.55$)$, textile products $(0.2)$, coke, oil refineries, and nuclear fuels $(0.05)$, chemical products (0.2), nonmetallic minerals (0.41), and basic metals (0.062) have a positive and significant effect on the total real industrial exports. Iranian Government can support its industry subsectors through the following strategies: 
- Directing labor force and expertise into subsectors with have comparative advantage.

- Giving investment priority to subsectors with high comparative advantage.

- Granting credits and loans of low interest rates in order to fund subsectors with high comparative advantage.

Therefore, the Iranian Government should pay attention to subsectors with higher comparative advantage through appropriate planning and prioritizing investments so that through benefitting from the advantage given by these subsectors, it can produce goods at a lower cost than other countries and thus to develop nonoil exports and to increase foreign currency incomes.

\section{References}

Balassa, B. (1965). Trade liberalization and revealed comparative advantage. Manchester School of Economic and Social Studies, 33, 99-124.

Cerra, V. \& Dayal- Gulati, A. (1999). China's trade flows: changing price sensitivities and the reform process. IMF Working Paper, No. 99/1, 1-37.

Changjun, Y. \& Hua, P. (2002). Dose comparative advantage explains export patterns in China? China Economic Review, 13, 276-290.

Dashti, G. H., Mohammad, K. H. \& Rasool, M. (2010). Analyzing comparative advantage and the structure of global pistachio export market. Journal of Economics and Agricultural Development, 1(3), 99-106.

Ghazijahani, S. (2000). A comparative study of comparative advantage in industry (via input-output table and linear planning. M.A Thesis in Economic Sciences: Al-Zahra University.

Goldstein, M. \& Khan, M. S. (1985). Income and price effects in foreign trade. In R.W. Jones, \& P. B. Keen (Eds.). Handbook of International Economics, 2, 1041-1105.

Jahangiri, K. H., Motefaker, A. \& Sadegh, G. H. (2011). An investigation of comparative advantage and prioritizing target markets of Iran's leather and skin industries. Journal of Economic Sciences, 11, 149168.

Lin, J., Cai, F. \& Li, Z. (1996). The China miracle: development strategy and economic reform. Hong Kong: Chinese University Press.

Monjazeb, M. (2002). Comparative advantage in Iran's clothing and food industries. Journal of Economics, 1( 7), 95-126.

Naderi, A. (2006). Comparative advantage and development of Iran's exports. Institution of Business Research and Studies Center.

Ohlin, B. (1933). Interregional and International Trade. Harvard University Press, Cambridge.

Pesaran, M. H., Shin, Y. \& Smith, R. J. (2001). Bounds testing approach to the analysis of level relationships. Journal of Applied Econometrics, 16, 289-326.

Serin, V. \& Civan, A. (2008). Revealed comparative advantage and competitiveness: A Case study for Turkey towards the EU. Journal of Economic and Social Research, 10(2), 25-41.

Trade Statistics Yearbook of Customs of Islamic Republic of Iran.

Smith, A. (1776). The Wealth of nations, Bantam Classics, England.

Smyth, D. A. (2005). Ireland's revealed comparative advantage. Quarterly Bulletin, 1, 101-114.

Utkulu, U. \& Dilek S. (2004). Revealed Comparative Advantage and Competitiveness: Evidence for Turkey visà-vis the EU/15. European Trade study Group $6^{\text {th }}$ Annual Conference, 1-26.

Valibeigi, H. \& Fereshte, R. (2004). Analyzing comparative advantage in Iran's tweedy weaving industry. Journal of Commerce, 30, 189-216. 